\title{
新第三紀・第四紀境界が变更されて意味するもの 一年代軸を取り入れた視点からの応用地質学—
}

井上大榮* ・幡谷竜太**

\section{1.はじめに}

新第三紀と第四紀の境界を約 180 万年前から 260 万年前に 変更することを骨子とする新しい第四紀の定義が2009年に IUGSで批准された(図-1). また，これに先立って，第三 紀の用語が廃され, 古第三紀と新第三紀を用いる, つまり, 新生代が，古第三紀，新第三紀，第四紀の 3 区分とされた. これらを受けて, わが国でも諸学会・シンポジウム等で定 義变更の是非が議論され，具体的な対応が始まった。

これら地質年代の定義变更を受け，応用地質の分野でむ， その対応を検討する必要があると考えられる。実際，「第 三紀」や「第四紀」などの時代名が入っている具体的な用 語を思い浮か心゙ると，「第四紀断層」「第四紀火山」「第三 紀層地すべり」などがある。そこで，ここでは何を变えな

新しい地質年代区分

\begin{tabular}{|c|c|c|c|c|c|}
\hline 代 & 紀 & 世 & \multicolumn{2}{|r|}{ 期 } & \multirow{2}{*}{$\begin{array}{l}\text { 年代 } \\
(\mathrm{Ma})\end{array}$} \\
\hline 界 & 系 & 統 & \multicolumn{2}{|r|}{ 階 } & \\
\hline \multirow{8}{*}{ 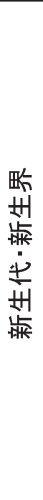 } & \multirow{5}{*}{ 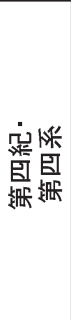 } & $\begin{array}{l}\text { 完新世:- } \\
\text { 完新統 }\end{array}$ & & & \multirow{4}{*}{$\begin{array}{l}0.0117 \\
<0.126\rangle \\
\langle 0.781\rangle\end{array}$} \\
\hline & & \multirow{4}{*}{$\begin{array}{l}\text { 更新世· } \\
\text { 更新統 }\end{array}$} & \multicolumn{2}{|c|}{ 後期·上部 } & \\
\hline & & & 中期· 中部 & (イオニアン) & \\
\hline & & & \multirow{2}{*}{ 前期· 下部 } & カラブリアン & \\
\hline & & & & ジェラシアン & 1.81 \\
\hline & \multirow{3}{*}{ 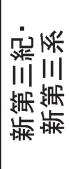 } & \multirow{2}{*}{$\begin{array}{l}\text { 鮮新世- } \\
\text { 鮮新統 }\end{array}$} & 後期· 上部 & ビアセンジアン & \multirow{3}{*}{$\begin{array}{l}3.00 \\
3.60 \\
5.33\end{array}$} \\
\hline & & & 前期·下部 & ザンクリアン & \\
\hline & & $\begin{array}{l}\text { 中新世- } \\
\text { 中新統 }\end{array}$ & \multicolumn{2}{|c|}{ 省略 } & \\
\hline
\end{tabular}

くてはならなくて, 何が变わらないのかの視点で, 今後応 用地質の社会でどのような対応をしていくのかを考えてみ たい。

\section{2. 定義変更のポイント}

第四紀の定義变更(図-1)の勧告を受けて，日本学術会議， 日本地質学会, 日本第四紀学会等, 日本国内での地球惑星 科学関係機関における検討・対応の経過の全容は, 奥村 ${ }^{1)}$, 遠藤・奥村 ${ }^{2}$ などを参照されたい。ここでは, それらの中 で応用地質の分野でとくに関連が深いと思われるものをま とめ，以下に紹介する.

（1）日本は新しい更新世・統，第四紀/系の定義を受け入 れて，今後これを使用する。新第三紀と第四紀の境界は, $1.81 \mathrm{Ma}$ か $2.58 \mathrm{Ma}$ 変更する.

従来の地質年代区分

\begin{tabular}{|c|c|c|c|c|}
\hline \multirow{10}{*}{ 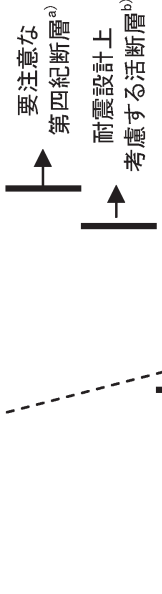 } & 紀 & 世 & & 期 \\
\hline & 系 & 統 & & 階 \\
\hline & \multirow{4}{*}{ 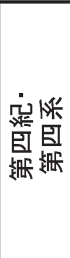 } & $\begin{array}{l}\text { 完新世・ } \\
\text { 完新統 }\end{array}$ & & \\
\hline & & \multirow{3}{*}{$\begin{array}{l}\text { 更新世· } \\
\text { 更新統 }\end{array}$} & \multicolumn{2}{|c|}{ 後期·上部 } \\
\hline & & & 中期·中部 & (イオニアン) \\
\hline & & & 前期·下部 & カラブリアン \\
\hline & \multirow{4}{*}{ 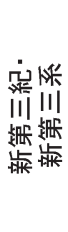 } & \multirow{3}{*}{$\begin{array}{l}\text { 鮮新世 · } \\
\text { 鮮新統 }\end{array}$} & \multirow{2}{*}{ 後期·上部 } & ジェラシアン \\
\hline & & & & ビアセンジアン \\
\hline & & & 前期·下部 & ザンクリアン \\
\hline & & $\begin{array}{c}\text { 中新世· } \\
\text { 中新統 }\end{array}$ & \multicolumn{2}{|c|}{ 省略 } \\
\hline
\end{tabular}

図-1＼cjkstart第四紀にかかわる新・旧区分の比較 奥村 ${ }^{11}$ に基づき作成. a)建設省河川局開発課 ${ }^{211}$ による. 閾值としては， 1 万年または 3 万年が 示されている，b)原子力安全委員会 ${ }^{16}$ による。後期更新世以降に活動した断層を対象としている，c)第四紀火山力夕ログ委員会編 ${ }^{23)}$ による。この文献では，200万年前以降に活動したことが認められる火山を第四紀火山としている，な技，「第三紀」は廃され，新 生代/界は, 古第三紀/系, 新第三紀/系, 第四紀/系の 3 つに区分される.

* (財) 電力中央研究所 Central Research Institute of Electric Power Industry (会員)（(現)東電設計(株) Tokyo Electric Power Services Co., LTD.)
** (財) 電力中央研究所 Central Research Institute of Electric Power Industry (会員) 
(2) 前期更新世・下部更新統にジェラシアン期/階を含め, 前期更新世・下部更新統は，カラブリアン期/階と合わせ て2つの期/階から構成されるものとする.

(3) 新第三紀/系と古第三紀/系を併せた地質時代として用 いられてきた，第三紀/系は非公式な用語として使用する ことができるが，学術論文，教科書，地質時代・年代層序 表には使用しない。

( 4 ) Neogene Period/System,Paleogene Period/System に対応する日本語として，新第三紀/系，古第三紀/系を従 来通り使用する。したがって，新生代・新生界は，第四紀 /系，新第三紀/系，古第三紀/系に 3 区分される.

（５）地質時代区分の名称としての沖積世・洪積世の使用は 廃し，完新世・更新世を使用することを徹底する。地層名 として慣用されている沖積層・洪積層は適切に定義される 場合，使用を認める.

\section{3. 応用地質学における年代軸を入れた視点の重要 性}

応用地質学の特徴として, 年代軸を入れた視点を用いて, 地質調査, 設計，施工，保守などへの対応ができることが 最大の強みであると言える。年代軸を入れた視点とは，地 層・岩体が堆積時や噴出時に有している初生的な性質と, その後どれだけの時間をかけて，どのような環境の中で獲 得した後生的な性質，言い換えれば地史の両者の側面から 勘案する軸である，具体的な例を以下にいくつか挙げる.

【例 $1:$ 岩石の固さ】

わが国の堆積岩では一般的に古い時代に堆積したものは 硬質である。この硬さには，堆積後に上方からの圧密作用 や構造運動を受けることによって脱水作用を起こし，さら に，堆積の環境やその後の続成作用により，化学的にさら に硬質化してきたという地史が反映されている。これは， 地質屋であれば，だれでも頭の中でわかっていて，その地 域に分布する堆積岩がどの時代のあのであるか， と調べれ ば，まず硬さがこのくらいだと頭に浮かぶものである。さ らに，地表に露出してからの経過時間や，日本列島のどこ に位置するかの場所がわかれば，風化作用などを受けるこ とによる軟質化を想定できるものである.

【例 2 : 地層・岩盤の分布】

構造物を作る際の基礎地盤や斜面として岩盤を考えると きには，対象とする岩盤の形成過程，形成年代，続成過程 を考慮に入れ, 経時変化を考慮して, 地質図, 岩盤区分図, 岩盤モデル図，力学的性質の測定などを経て，設計の段階 に入る。言うまでもなく，このような思考過程が，土木系 の分野之差別化される重要な部分である.

【例 3 : 未固結層の分布】

構造物の基礎，トンネル，斜面の安定などの設計におい ては，沖積層，洪積層などの碟，砂，泥，段丘礫層，崖錐
堆積物，土壌などの軟らかくて固結していない地層を考慮 しなければならない。これらは，一般的には強度や変形性 が小さい，透水性が高いといった特徵があり，まずその分 布を調查して，力学的・物理的性質を測定して，切り取り 勾配，置き換え深さ，支保の種類，杭の深さなどの工法を 選定する。これらは，全て第四紀というキーワードに関連 したあのであり，特にその分布を考えるうえで，第四紀に おける地史の考察は欠かせない。

【例 $4:$ 透水性が高い火山岩】

火山性の地層の場合，急冷によって形成された節理群を 通して透水性が高いのが一般的であり，新しい火山から噴 出した岩石(岩盤)ほど続成作用を受けている時間が少ない ので，より透水性が高い傾向がある。第四系であるか否か に関わらず，そのような問題が考えられる場合には，透水 試験や河川の流量測定などを行って，実際の構造物である ダムやトンネルなどの設計に対処するが，第四紀の火山岩 であることが文献等からわかっていれば，サイト選定の意 思決定に際し，重要な情報となる。

このように，応用地質学にとって，年代軸を入れた視点， 言い換えれば，時間を含めた四次元の概念は大変重要であ る。しかしながら，第四紀の定義の变更がこれらの考え方 に影響するかといえば，必ずしもそうではない，本質的に 重要なのは, 問題・課題解決にあたり, 時間の概念をいか に使うかということである。

\section{4. 法的な規制や民間規格で「第四紀」の用語が用 いられている例}

ダム，原子力発電所，放射性廃棄物処分場などの重要構 造物を設計する際には，活断層や火山の将来の活動に留意 しなければならない。それらの自然現象を将来予測するた めには，過去の活動の法則性を調査したうえで，それを外 挿するのが一般的である。どのぐらいの過去まで遡るか， それを将来どのように考えるかは，エンジニアそれぞれの 科学観・工学観によるものが大きいが，上記のような重要 構造物の設計に対しては，法的な規制，民間指針，事業者 の自主基準などにより定められ，その中に第四紀に関わる あのあある．ただし，第四紀の定義が変更されたからといっ て, 遡って検討対象を増やすことに対しては慎重な検討が 必要と思われる，以下に，地質調査・評価における第四紀 に関連した規制・規格について主なむのを紹介する。

\section{1 活断層}

表-1に活断層に関わる主な文献に示された活断層の定義 をまとめた ${ }^{3) \sim 12)}$. 基本的には, 多田 ${ }^{3)} の$ 定義が踏襲されて おり，どのぐらい過去まで遡って考えるかという点で差が 見られ，第四紀全体を考えるむのと第四紀の後期を考える あのとがある．次に，表-2に原子力発電所の建設，余裕深 度処分事業，地層処分事業に打いて示されている，あるい 
表 -1 活断層の定義の例

\begin{tabular}{|l|l|}
\hline \multicolumn{1}{|c|}{ 文献等 } & \multicolumn{1}{c|}{ 定義の内容 } \\
\hline 多田(1927) 活断層の二種類 ${ }^{3)}$ & $\begin{array}{l}\text { 極めて近き時代まで地款運動を繰り返した断層であり, 今後も活動する可能性の大 } \\
\text { (なる断層. }\end{array}$ \\
\hline 吉川ほか (1973) 新編日本地形論
\end{tabular}

表-2 工学的に考慮する活断層の考え方・定義の例

\begin{tabular}{|c|c|}
\hline 文献等 & 定義の内容 \\
\hline $\begin{array}{l}\text { 土木学会(2001) } \\
\text { 概要調査地区選定時に特に考慮すべき要件 }{ }^{13)}\end{array}$ & $\begin{array}{l}\text { 第四紀後期(過去数 } 10 \text { 万年以内) に繰り返し活動している断層は将来的に活動する可 } \\
\text { 能性があるものとし，概要調査地区選定にあたって除外することが必要である. }\end{array}$ \\
\hline $\begin{array}{l}\text { 原子力安全委員会 (2002) } \\
\text { 概要調査地区選定時に考慮すべき環境要件 }{ }^{14)}\end{array}$ & $\begin{array}{l}\text { 「処分施設を合理的に配置することが困難となるような活断層」を(中略) 概要調杗 } \\
\text { 地区に含めない. }\end{array}$ \\
\hline $\begin{array}{l}\text { 土木学会 (2006) } \\
\text { 精密調査地区選定時に考慮すべき要件 }{ }^{15)}\end{array}$ & $\begin{array}{l}\text { 高レベル放射性廃棄物地層処分で概要調查およびそれ以降に検討の対象とする活断 } \\
\text { 層を「第四紀の後半以降繰り返し活動し，中位段丘面または中位段丘構成層以降の } \\
\text { 地層に影響を与えている断層」とし，これを避ける必要があるとした } \\
\text { 第四紀の後半 : } 30 \text { 万年前程度以降(岡田・東郷 }{ }^{10)} \text { を踏襲 } \\
\text { 中位段丘 : MISS から MIS6 に形成された海成およひ河成の段丘 }\end{array}$ \\
\hline $\begin{array}{l}\text { 原子力安全委員会 (2006) } \\
\text { 原子力発電所の耐震設計審査指針 }{ }^{16)}\end{array}$ & $\begin{array}{l}\text { 活断層を「最近の地質時代に繰り返し活動し，将来も活動する可能性がある断層」 } \\
\text { と定義した．また，耐震設計上考慮する活断層を「後期更新世以降の活動が否定で } \\
\text { きないも」のとする. なお，その認定に際しては，最終間水期の地層または地形面 } \\
\text { に断層による変位·変形か認められるか否かによることができる. }\end{array}$ \\
\hline $\begin{array}{l}\text { 原子力環境整備機構 (2009) } \\
\text { 概要調査地区選定上の考慮事項 }{ }^{17)}\end{array}$ & $\begin{array}{l}\text { 「過去数 } 10 \text { 万年以降繰り返し活動したことがある断層で, 将来も活動する可能性か } \\
\text { ある断層」を活断層とし， これを「最終処分施設の著しい変形を生じさせるような } \\
\text { 岩盤を破壊・破断を発生させるもの」として考慮する. }\end{array}$ \\
\hline $\begin{array}{l}\text { 原子力安全委員会 (2010) } \\
\text { 余裕深度処分の管理期間終了以後における安 } \\
\text { 全評価に関する考え方 }\end{array}$ & $\begin{array}{l}\text { 活断層とは，後期更新世以降の活動が否定できない断層を意味するものとするが, } \\
\text { 将来にわたって現在のテクトニクスか変化しつつあるという知見か得られている地 } \\
\text { 域では，必要に応じてその変動傾向を適切に勘酶する. }\end{array}$ \\
\hline
\end{tabular}


は，提案されている工学的に考慮する活断層の考え方をま とめた ${ }^{13)}$ 18). これらのうち，規制側の原子力安全委員 会 ${ }^{16), 18}$ が，表-1に示した活断層の定義よりあ踏み込んだ定 義を与えている点に注目されたい. 実際の活断層調査では, 最む新しい活動の年代だけしかわからないことが多く, 実 務に対応した定義である。両者は，「後期更新世以降の活 動が否定できないもの」，つまり，約13万年前以降に活動 したものを対象としており，今回の第四紀の定義変更には 影響されない.

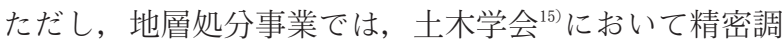
查地区選定時の考慮すべき断層の定義にかかわる提案があ るが，これに対応した具体的な定義はまだ決まっていない。 長期にわたる安全確保の観点から，第四紀に活動した断層 をすべて考慮すべきではないかとの見解もある ${ }^{19,20)}$. しか し，地震を起こした結果生じる活断層は, 現在のテクトニ クスに支配されていることを考慮すると，第四紀の始まり まで遡ることは過度に保守的な評価であると考えられ，今 後より本質的かつ現実的な検討が望まれる.

一方, ダムに関しては, 『ダム建設における第四紀断層 の調査と対応に関する指針(案)』が出されている。これ は指針(案)とされており，どのように実際用いられている かは不明であるが，ここでは第四紀に地表に変位を生じさ せた断層を「第四紀断層」と定義し，さらに，(1)最終活動 時期が 1 万年前以降，(2)最終活動時期が 1 万年前 3 万年 前の断層でかつ長さが長いもの, (3)第四紀後期に繰り返し 活動した規模が大きい第四紀断層，のいずれか一項目に該 当するものを「要注意な第四紀断層」と定義している。そ こで，要注意な第四紀断層がダム敷に存在することが判明 した場合には，調查結果を総合判断して，ダムの位置の变 更を含む適切な措置をとるむのとしている。これを読む限 り，第四紀の定義変更の影響はない。

\section{2 火山}

火山活動については, 現行の原子力発電所に関して, 『原子力発電所火山影響評価技術指針』22)では，調査対象の 火山は「第四紀に活動した火山」とするとの記載がある. また，高レベル放射性廃棄物の地層処分事業では，『特定 放射性廃棄物の最終処分に関する法律 (法律第百十七号)』 における概要調查地区の選定要件や，概要調査地区選定上 の考慮事項 ${ }^{17)}$ などにおいて, 調査の対象を第四紀火山とす る旨の記載がある。

実際の地点を検討する場合，『日本の第四紀火山カタロ グ』23)が参考にされることになり，新しい定義に沿って第 四紀火山カタログのデータが更新されれば，「第四紀火山」 あ増えることになるが，増えた分を，工学的に考慮するこ とについては，十分な議論をすべきであろう。むしろ，こ れを契機に，今後活動する可能性がある火山の定義につい て，改めて本質的に議論されることが望まれる.

\section{3 その他}

地層処分事業では，最終処分を行おうとする地層として， 第四紀の未固結堆積物を除外している年年と。 しかし，具体 的な事例を考慮すると，形成年代によらず，強度が小さい 未固結の地層に処分施設を建設することの経済性を考えれ ば現実的ではなく，第四紀の定義变更はとくに問題にはな らないと思われる。

\section{5.「第三紀層地すべり」「洪積」などの用語の使い 方について}

地すべりにかかわる用語として，「第三紀層地すべり」 が使われている ${ }^{24)}$.「第三紀層地すべり」は主に新第三紀 に海底に厚く堆積した地層が，まだ未固結や半固結の状態 のときに，とくに層面などの弱い面に沿って滑ったという 特徽を有する。わが国で新第三紀層が分布する地域にはこ のタイプの地すべりが多く分布している．「第三紀層地す ベり」は上記のような事情で命名されたもので，実務的に あ意味がある用語である。学術的には第三紀を使わないと しても，実用的には「新第三紀層地すべり」といったかた ちに変えて，今後も使われるあのと思われる。

「洪積」の用語は「洪積世」「洪積層」「洪積台地」「洪積 粘土」といったかたちで，現場で広く使われている。これ らは，多くの現場経験に基づいて，それぞれ対応する現象 や物が頭に浮かんで，それがどのような環境で作られ，ど のような過程を経て, 現在の硬さになったのかが想定でき る用語である。今回の定義变更に伴い, 「沖積世・洪積世 の使用は廃し，完新世・更新世を使用することを徹底する 地層名として慣用されている沖積層・洪積層は適切に定義 される場合使用を認める.」とされている ${ }^{1)}$. 今後, 時代 区分の用語としての「洪積世」を用いないことには異存は ない。しかし，ある種の地層を表現する慣用的な用語とし て,「洪積層」「洪積台地」「洪積粘土」を明確な定義のも とで継続して使えれば，利点も多いと思われる.

\section{6. おわりに}

最初に述べたように，応用地質の分野における調査・設 計は地層・岩体の形成過程，その後の続成過程等を考えな がら，年代軸を意識しており，そして，強度・变形性・異 方性を考慮に入れて調査・設計しているために，第四紀の 定義変更に左右されることは，本質的にはあまりない。た だし，さまざまな文書における表記の変更等の課題は残る。 しかしながら，法的規制や学会基準では「第四紀」の言葉 を用いて書かれているものがあることから，今後実際に対 応する場合には，実情に応じた工夫が必要になると予想さ れ，科学的にも，社会的にも見解を決めておくことが望ま れる。自然科学は法律や規則で将来予測できるものではな いが，多くの意見が生じる学問分野であるだけに，早いう 


\section{ちに議論しておくことが重要である.}

謝辞 本報告は2010年 1 月 22 日日本学術会議で行われた公 開シンポジゥム「人類の時代一第四紀は残った」において 「日本の第四系一応用地質における第四系」と題して井上 が報告した内容 ${ }^{25}$ をむとに作成したものである。発表の機 会を与えていただいたシンポジゥム開催関係者に謝意を表 します。

\section{引用 文 献}

1）奥村晃史 (2010)：第四紀の新しい定義：人類の未来を開く鍵 として, JGL, Vol.6, No.2, pp.1-3.

2）遠藤邦彦・奥村晃史 (2010)：第四紀の新たな定義：その経緯 之意義についての解説，第四紀研究，Vol.49，No.2，pp.6978.

3）多田文男(1927)：活断層の二種類, 地理学評論, Vol.3, No. 10, pp.980-983.

4) 吉川虎雄・杉村新・貝塚爽平・太田陽子・阪口豊(1973)：新 編 日本地形論, 東京大学出版会, $415 \mathrm{p}$.

5）地質調査所環境地質部地震地質課 (1983)：50万分の 1 活構造 図シリーズについて，地質調査所月報，Vol.34，No.1，pp.27 -37 .

6）日本第四紀学会編 (1987)：日本第四紀地図, 東京大学出版会.

7）岡田篤正 - 中田高 - 千田昇 - 池田安隆・ 今泉俊文・渡辺満久 ・ 長岡信治・前圭英明・九州活構造研究会編 (1989)：九州の活 構造, 東京大学出版会, 553p

8）活断層研究会編 (1991)：新編日本の活断層一分布図と資料一, 東京大学出版会, 363p.

9）国土地理院：都市圏活断層図, http://www1.gsi.go.jp/ geowww/bousai/legend.html，2010.12.21最終閲覧.

10）岡田篤正・東郷正美編 (2000)：近畿の活断層, 東京大学出版 会, 395p
11）中田高・今泉俊文編 (2002)：活断層詳細デジタルマップ，東 京大学出版会.

12）産業総合研究所：RIO-DB活断層データベース, http:// riodb02.ibase.aist.go.jp/activefault/，2010.12.21最終閲覧.

13）土木学会 (2001)：概要調査地区選定時に特に考慮すべき要件, 土木学会.

14）原子力安全委員会 (2002)：高レベル放射性廃棄物処分の概要 調査地区選定段階における環境要件について。

15）土木学会(2006)：精密調査地区選定時に考慮すべき要件，土 木学会.

16）原子力安全委員会 (2006)：原子力発電所の耐震設計審査指針

17）原子力環境整備機構 (2009)：概要調査地区選定上の考慮事項, 高レベル放射性廃棄物の最終処分施設の設置可能性を調査す る区域の公募関係資料 -3

18）原子力安全委員会 (2010)：余裕深度処分の管理期間終了以後 に打ける安全評価に関する考え方。

19）深部地質環境研究センター編 (2007)：概要調査の調査・評価 項目に関する技術資料一長期变動と地質環境の科学的知見と 調査の進め方一，地質調査総合センター研究資料集，No.459。

20）梅田浩司・安江健一・浅森浩一(2010)：高レベル放射性廃棄 物の地層処分に打ける断層研究の現状々今後の展望, 月刊地 球, Vol.32, No.1, pp.52-63.

21）建設省河川局開発課 (1974)：ダム建設における第四紀断層の 調査と対応に関する指針(案).

22）日本電気協会原子力規格委員会 (2009)：原子力発電所火山影 響評価技術指針，JEAG4625-2009，14p.

23）第四紀火山カタログ委員会編(1999)：日本の第四紀火山カ夕 ログ，日本火山学会.

24）地学団体研究会 (1996)：新版地学辞典, 平凡社.

25）井上大榮 (2010)：日本の第四系一応用地質に招ける第四系, 公開シンポジゥム「人類の時代一第四紀は残った」, 日本学 術会議.

（2010年11月 8 日受付，2011年 1 月20日受理）

Jour. Japan Soc. Eng. Geol., Vol.52, No.1, pp.14-18, 2011

\section{Consideration on the Effect of the New Quaternary Period -Engineering Geology Based on Time Line-}

Daiei INOUE and Ryuta HATAYA 